\title{
Foraging-farming transitions at the Niah Caves, Sarawak, Borneo
}

\author{
Graeme Barker ${ }^{1}$, Lindsay Lloyd-Smith ${ }^{1}$, Huw Barton ${ }^{2}$, \\ Franca Cole ${ }^{3}$, Chris Hunt ${ }^{4}$, Philip J. Piper ${ }^{5}$, Ryan Rabett ${ }^{1}$, Victor Paz ${ }^{5}$ \\ $\&$ Katherine Szabó ${ }^{6}$
}

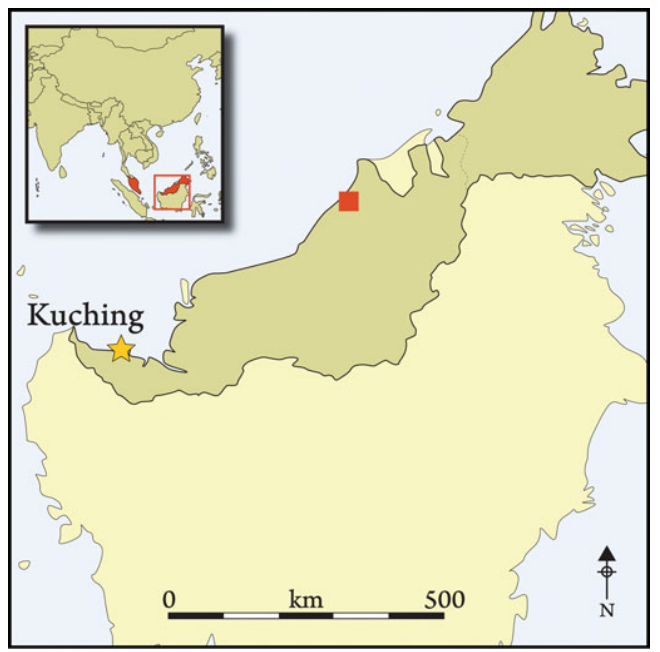

The Niah Caves in Sarawak, Borneo, have captured evidence for people and economies of 8000 and 4000 years ago. Although not continuous on this site, these open two windows on to life at the cultural turning point, broadly equivalent to the transition from Mesolithic to Neolithic. They have much in common, inferring that the occupants, perhaps belonging to an older maritime dispersal, had a choosy appetite for the Neolithic package.

Keywords: Borneo, Niah Caves, Neolithic, Mesolithic, farming, foraging

\section{Introduction}

For more than two decades our present understanding of the prehistory of Island Southeast Asia (Figure 1) has been shaped fundamentally by Peter Bellwood's arguments that the foraging-farming transition can best be explained in terms of a maritime migration of Austronesian-speaking Neolithic farmers (Bellwood 1988, 1990, 1996a \& b, 1997, 2004; Diamond \& Bellwood 2003). The chronology proposed by linguists such as Blust (1976)

\footnotetext{
McDonald Institute for Archaeological Research, University of Cambridge, Cambridge CB2 3ER, UK

School of Archaeology and Ancient History, University of Leicester, Leicester LE1 7RH, UK

Department of Archaeology, University of Cambridge, Cambridge CB2 3DZ, UK

School of Geography, Archaeology and Palaeoecology, Queen's University Belfast, Belfast BT7 1NN, UK

Archaeological Studies Program, University of the Philippines, Quezon City 1101, Philippines

6 School of Earth and Environmental Sciences, University of Wollongong, NSW 2522, Australia
}

Received: 23 December 2010; Accepted: 24 January 2011; Revised: 3 February 2011

ANTIQUITY 85 (2011): 492-509

http://antiquity.ac.uk/ant/085/ant0850492.htm 


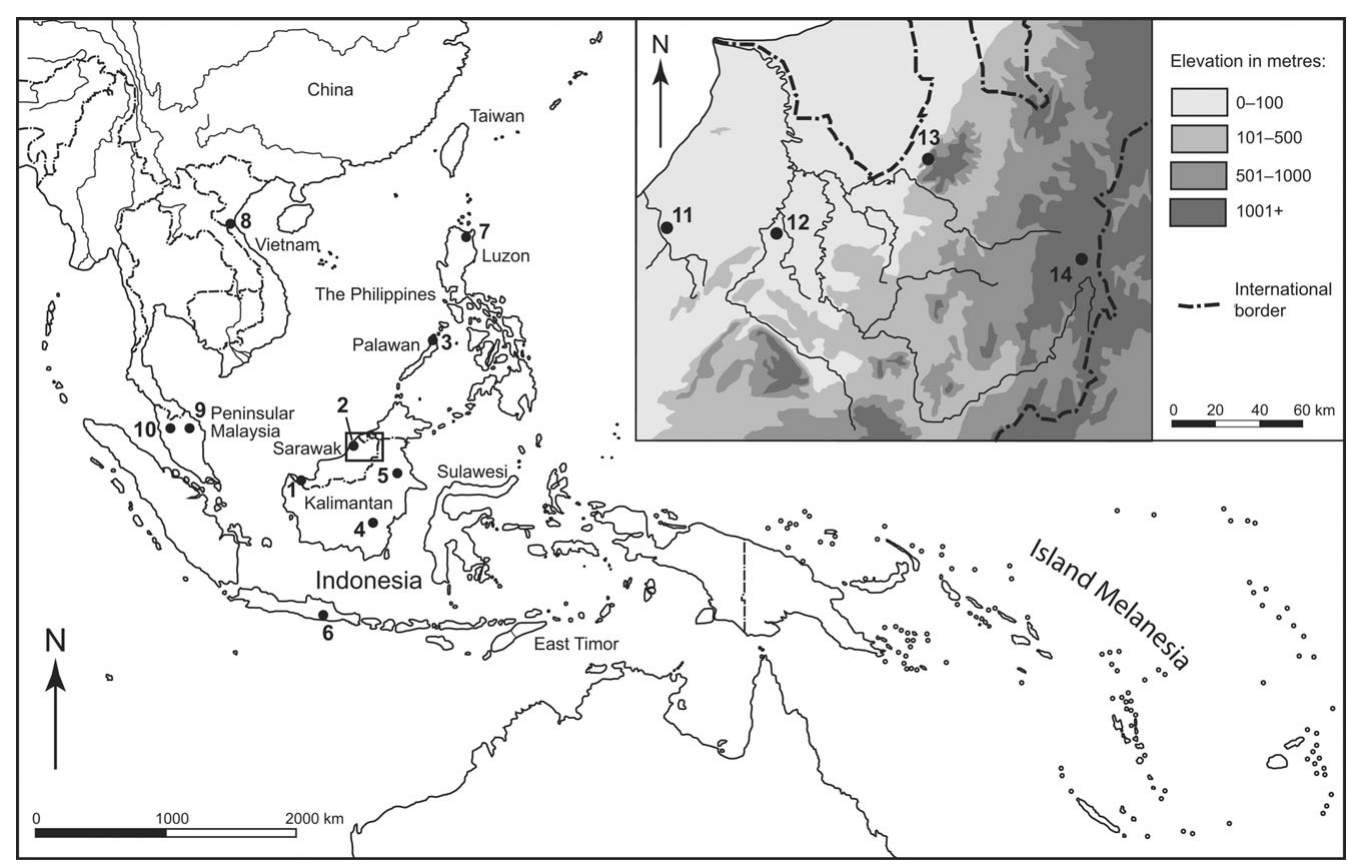

Figure 1. Island Southeast Asia, showing the principal regions and sites mentioned in the paper: 1) Gua Sireh; 2) Gunung Subis (Niah Caves complex); 3) Ille Cave; 4) Gua Tengkorak; 5) Kimanis; 6) Gunung Sewu (Song Terus, Song Keplek, Gua Braholo); 7) Nagsabaran; 8) Da But coastal sites; 9) Gua Cha and Gua Peraling; 10) Gua Teluk Kelawar; 11) Niah Caves; 12) Loagan Bunut; 13) Lobang Angin; 14) Kelabit Highlands.

and Pawley and Green (1973) for the spread of Austronesian languages appeared to correlate with the emerging radiocarbon chronology for the first appearance of Neolithic material culture in the region: sites with Neolithic pottery dated to $c .6000 \mathrm{BP}$ in the Philippines, in Sulawesi to $c .5000 / 4500 \mathrm{BP}$, and in East Timor to $c .4000 \mathrm{BP}$ (Bellwood 1985). Charred remains of domestic rice (Oryza sativa) in sediments, and as inclusions in pottery in the same sediments, at Gua Sireh Cave in Sarawak in northern Borneo were dated to c. $4300 \mathrm{BP}$ (Bellwood et al. 1992), and domestic rice in the Phillipines dated to c. $3300 \mathrm{BP}$ (Snow et al. 1986). In combination, the linguistic and archaeological evidence suggested what Diamond (1988) described as the 'Express Train' model of the beginnings of farming: a maritime spread of Austronesian-speaking Neolithic colonists from mainland China and Taiwan to the Philippines, Borneo and Melanesia between about 5000 and 3000 BP, taking pottery, rice cultivation and domestic livestock (pigs, dogs, chickens) with them. These colonists either displaced or absorbed any pre-existing populations of foragers.

At about the same time as Peter Bellwood's initial publications on the 'Express Train' thesis, Wilhelm Solheim (1984) proposed a very different model: he suggested that an increasingly maritime-oriented culture would have developed amongst Early and Mid Holocene foraging populations in Island Southeast Asia in the context of the flooding of 'Sundaland', the huge area (the size of Western Europe) that had been exposed by lower sea levels in the Pleistocene in response to glacier growth. Enhanced maritime connections would have led to the development of cultural and linguistic similarities and the exchange of material culture 


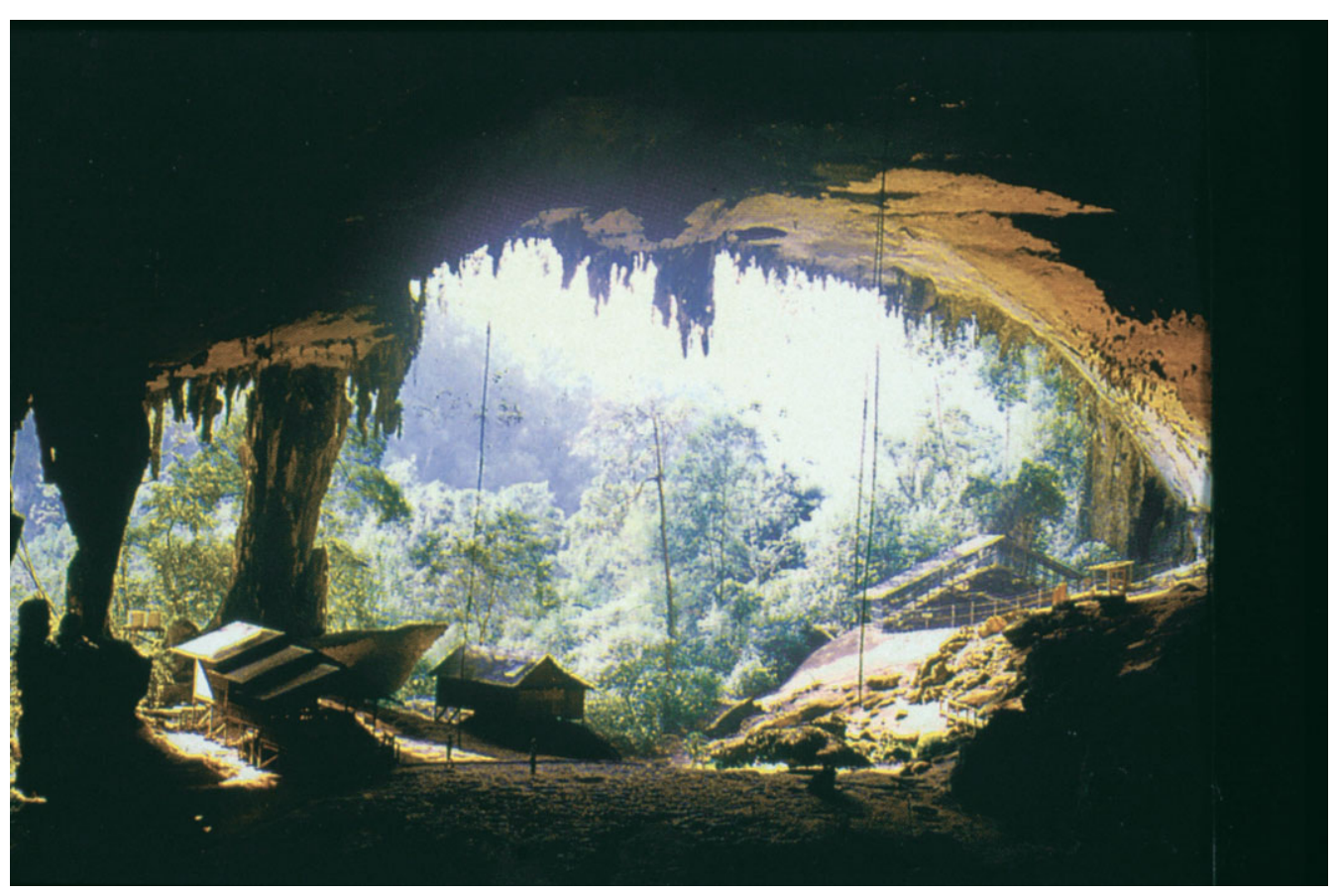

Figure 2. The West Mouth of Niah Great Cave. The main archaeological zone is on the far right (photograph: G. Barker).

and agricultural resources. He termed his theory the 'Nusantao hypothesis', Nusantao being a term constructed from the Austronesian stem words for 'island' and 'people'.

The present paper reviews the evidence for Early and Mid Holocene settlement in the Niah Caves in Sarawak in the light of these competing 'meta-narrative' theories about the probable course of foraging-farming transitions in the region. The caves consist of a series of enormous interconnected caverns and numerous smaller caves, located in the Gunung Subis massif about $15 \mathrm{~km}$ inland from the north Borneo coast. Excavations by Tom and Barbara Harrisson in the 1950s and 1960s exposed a long sequence of Pleistocene and Holocene occupation, which they dated from around 40000 years ago to the present day (T. Harrisson 1957, 1958, 1965, 1970; B. Harrisson 1967). The discoveries in the most intensively investigated entrance, the West Mouth of Niah Great Cave (Figure 2), included 25 human burials dating to the Early Holocene, and over 200 burials with Neolithic material culture, comprising respectively the largest Mesolithic and Neolithic cemeteries in Island Southeast Asia. The Harrisson excavations removed most of the Early and Mid Holocene archaeological deposits in the major cave entrances. A programme of renewed fieldwork in 2000-2003 (the Niah Caves Project or NCP, coordinated by GB), augmented by an extensive programme of re-dating and geomorphological analyses and archival study, has been able to reconstruct the stratigraphy and occupation history of the West Mouth. This has been done through studying the remaining section baulks and exposed sections coupled with targeted excavations (Barker et al. 2007, in press). The new dating suggests that the Early Holocene use of the West 
Mouth (c. $11500-8000$ BP) was followed by a gap of some 4000 years, the Neolithic cemetery dating to $c .4000-2000 \mathrm{BP}$.

How similar or different were the societies on either side of this hiatus and can those similarities and differences inform on the Austronesian debate? For convenience these societies are termed here respectively 'Mesolithic' and 'Neolithic', the terminology usually used to differentiate between Holocene pre-agricultural hunter-gatherers and farmers, but as the discussion will show, such terms are not very helpful in the case of the societies using the Niah Caves.

\section{Early Holocene environments and 'Mesolithic' subsistence}

The inundation of the Sunda shelf following the onset of global warming in the Terminal Pleistocene resulted in the landscape around the Niah Caves being invested with tidal swamp forest and high-canopy closed rainforest. Two pollen cores taken from sediments near the caves have dark bluish-grey laminated clays at the bottom indicative of a tidal mangrove swamp. On the evidence of Casuarina and Dodonaea, there was a sandy coastal barrier beyond the swamp. At a transition dated by ${ }^{14} \mathrm{C}$ to $5710 \pm 80 \mathrm{BP}$ or $6670-6310 \mathrm{cal}$ BP (Beta-193909) in one core and to 5160 60 BP or 6000-5850 cal BP (Beta-193910) in the other, these pass into dark brown peaty clays and then into dark brown wood peat, indicative of less saline environments characterised by back mangrove swamp. The more open vegetation that now developed around the caves was associated with repeated evidence for localised burning indicative of human clearance activities (Hunt \& Rushworth 2005). A pollen core from the Loagan Bunut lake c. $50-60 \mathrm{~km}$ inland from Niah has similar evidence for anthropogenic activity there from the beginning of the Holocene, in a landscape dominated by rainforest. (Burning had in fact been a characteristic of human land use at Niah since the first occupation by modern humans $c .50000$ years ago: Barker et al. 2007.)

The main evidence for the nature of human occupation at Niah in the Early Holocene comes from two areas in the West Mouth (Figure 3). The northern wall of the cave at the entrance forms a prominent rock overhang. The Harrisson excavations here revealed stratified deposits from 18 inches $(0.46 \mathrm{~m})$ below the ground surface to a maximum depth of 154 inches $(1.37 \mathrm{~m})$. These contained fragmented animal bone, shells, lithic and bone artefacts, and a cluster of flexed burials between 25 and 50 inches $(0.64-1.28 \mathrm{~m})$. Charcoal retrieved from the Harrisson Excavation Archive in Sarawak Museum, Kuching, has yielded ${ }^{14} \mathrm{C}$ dates from these levels, in stratigraphic order, between $13745 \pm 55 \mathrm{BP}$ or $16704-17$ $042 \mathrm{cal} \mathrm{BP}(\mathrm{OxA}-15162)$ and $7606 \pm 35 \mathrm{BP}$ or $8354-8454 \mathrm{cal} \mathrm{BP}$ (OxA-15161). In addition to re-studying all these materials, the NCP team collected another set of Early Holocene occupation evidence by excavating a $3 \times 1 \mathrm{~m}$ trench some $70 \mathrm{~m}$ into the cave, in the 'twilight zone' behind the Neolithic burials. This revealed midden deposits containing fragmented animal bone, whole and fragmented shells, bone tool fragments, lithic debitage and plant remains including charred parenchymatous tissues and nut fragments. Charcoal from these layers yielded four dates in sequence between $10000 \pm 55 \mathrm{BP}$ or $11263-11742 \mathrm{cal} \mathrm{BP}$ (OxA-11865) and 7948土39 BP or 8645-8981 cal BP (OxA-18358).

The main prey killed by the people camping in the caves in the Early Holocene was the bearded pig (Sus barbatus), especially juveniles and sub-adults. A range of primates 


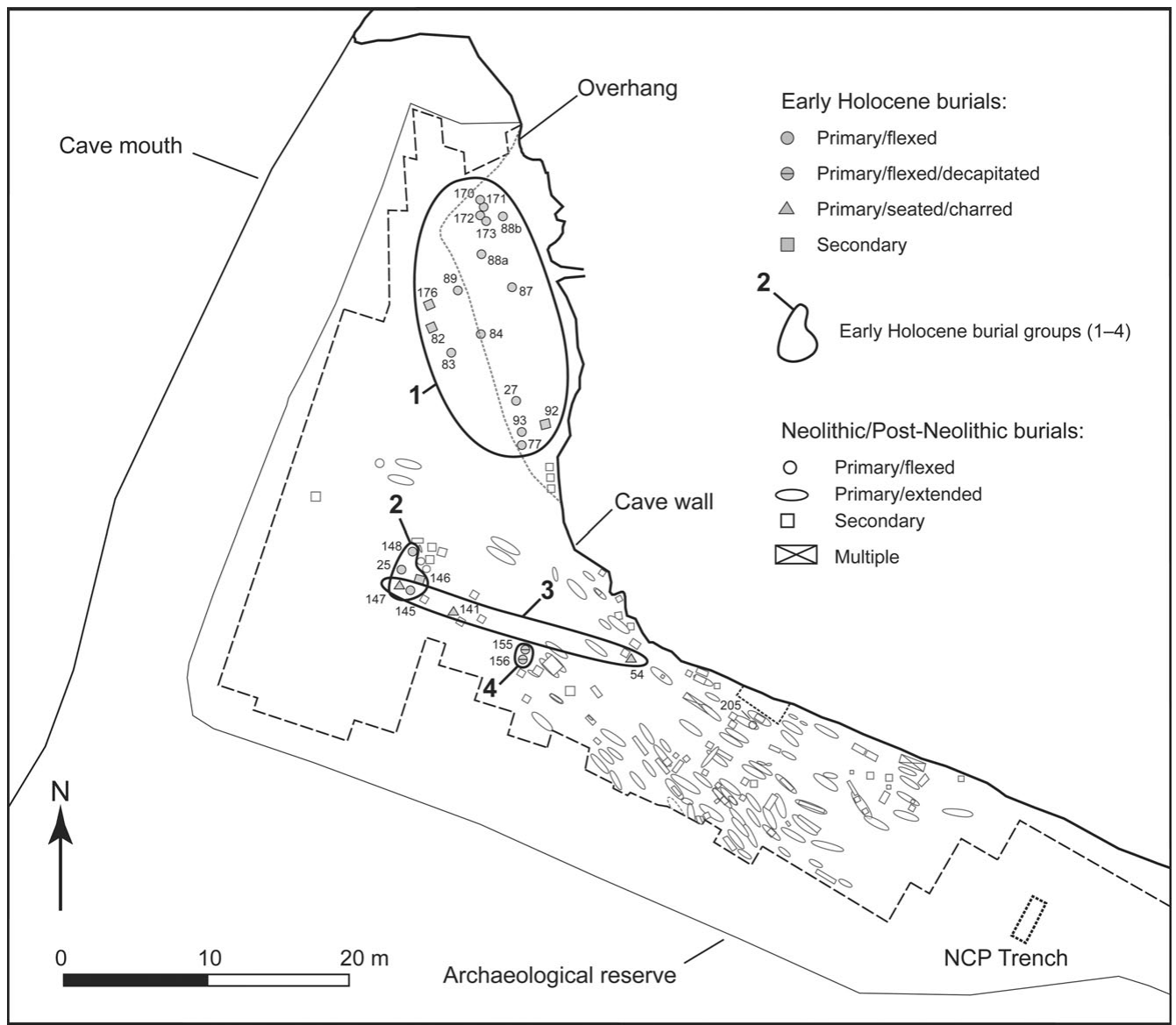

Figure 3. The West Mouth of Niah Great Cave: plan of the archaeological zone, showing the positions of the burials and trenches discussed in the text.

including orangutan, gibbon, leaf monkey and long-tailed macaque and rare examples of large browsing ungulates such as cattle, tapir, and various deer (sambar, muntjac, mouse deer) are also represented in the faunal assemblage. These fauna are predominantly of high-canopy closed rainforest. There are also species of coastal swamp, especially numerous remains of the Asian soft-shelled turtle (Amyda cartilaginea). Most of the molluscs collected were also brackish-water species, the most common being Neritodryas subsulcata and Neritina petitii. Plant remains were mainly rainforest rather than coastal swamp species. They included: Canarium, Elaeocarpus and Pangium edule nuts, parenchyma fragments with cellular sizes and structures indicative of yam (Dioscorea alata) and taro (Colocasia cf. esculenta) and charred seeds of Cucurbitae (the cucumber family) and Cyperaceae (the sedge family). Many of them would have required careful processing to remove toxins. In combination, the data indicate that the people using the West Mouth in the Early Holocene foraged in the tidal waterways and coastal mangrove swamps, but relied especially on resources of the rainforest, the density or regularity of which they enhanced by forest burning, presumably 
by clearing edges of openings to encourage species such as yam and taro for themselves to exploit, and to attract the pigs that formed their primary prey.

These foraging systems are closely paralleled at Ille Cave in Palawan in the southern Philippines (Szabó et al. 2004; Lewis et al. 2008; Piper et al. 2011). Animal bones consist mainly of various deer and pig, along with monkeys and small carnivores. Burnt botanical remains in the Early Holocene levels identified by Jane Carlos (Barker et al. 2011) include Canarium nuts and parenchyma of wild yam (Dioscorea hispida), (probably) the modern domesticated yam (Dioscorea alata) and taro (Colocasia cf. esculenta). The presence of parenchyma identical to those of the modern domesticated yam at Ille Cave in secure stratigraphic contexts provides extremely strong evidence that it was being intensively exploited by people in Palawan thousands of years before the supposed Austronesian expansion.

The hunting technologies associated with Early Holocene foraging probably included traps and snares (indicated by the ages of the animals killed), throwing spears and the bow and arrow - the latter on the evidence of stingray spines ground to slender points and with traces of resin and fibre binding (Barton et al. 2009). The stone technologies included a basic core and flake reduction sequence as in the Late Pleistocene but also a variety of ground and polished stone artefacts used (on the basis of usewear and residue evidence) for grinding and pounding plant matter. These technological developments coincide with evidence for a shift towards more extended periods of habitation and perhaps the storage or caching of some less portable artefacts in anticipation of repeated site visits. The most significant visible change in the character of human presence at this time, however, compared with during the Late Pleistocene, is the use of the West Mouth for burial as well as habitation.

\section{'Mesolithic' ritual practice and burial}

As part of the original study of the West Mouth burials by Shelagh and Richard Brooks, a series of ${ }^{14} \mathrm{C}$ dates was obtained from samples of bone collagen and apatite (T. Harrisson 1975; Brooks et al. 1977). The reliability of the apatite samples was immediately questioned because they produced the oldest dates with the widest error ranges (Brooks et al. 1977: 28). The reliability of the bone collagen ${ }^{14} \mathrm{C}$ dates has also been questioned (Spriggs 1989), but there is in fact a good level of agreement between most of these and new ${ }^{14} \mathrm{C}$ dates obtained from organic materials from selected graves (Lloyd-Smith 2009). The careful examination by Lloyd-Smith of the contextual and stratigraphic information contained in the excavation notebooks kept by Barbara Harrisson, combined with the old and new ${ }^{14} \mathrm{C}$ dates, indicates that Early Holocene foragers practised elaborate and varied burial rituals in the West Mouth (Table 1).

The main burials form two distinct clusters, one under the rock overhang (hereafter termed Burial Group 1) and the other, Burial Group 2, located several metres to the south at the front of the cave mouth (Figure 3). The commonest form of burial consisted of the body being placed in a pit in the foetal position ('flexed burial'; Figure 4). In some instances pigmentation was applied to the skulls. Archive photographs indicate that the dead were placed in substantial graves at least $0.6 \mathrm{~m}$ deep. The relative positions of several burials in Burial Group 1 can also be reconstructed from photographs and drawings in the Harrisson 
Table 1. Proposed Early Holocene burial groups in the West Mouth, Niah Great Cave, Sarawak (after Lloyd-Smith 2009).

\begin{tabular}{ll}
\hline Burial group & Description \\
\hline 1 & Thirteen flexed burials, two secondary burial cremations, and one unburnt \\
secondary burial clustered under and around overhang at north-west \\
corner of cave mouth. All burials found at depths of between 0.64 and \\
$1.27 \mathrm{~m}$. Two possible sub-groups identified: Group 1A comprising a \\
cluster of six flexed burials under north end of overhang; Group 1B \\
formed by cluster of three flexed burials at southern end of overhang. \\
Open-air cluster of three flexed burials, and possibly one unburnt \\
secondary burial, located at end of slight ridge-line falling out from cave \\
interior. Found at depths of between 0.51 and 1.12m. Spatially \\
overlapping with Burial Group 3. \\
Seated burials: B54, B141 and B147. Located along a ridge from B147 in \\
the vicinity of Burial Group 2, to B54 located $c .35 \mathrm{~m}$ into the cave. \\
Seated burials were found at depths between 0.45 and 0.90m. \\
Adjacent pair of decapitated flexed burials (B155 and B156), laid \\
back-to-back. Located 10m east into the cave from Burial Group 2, and \\
on the western edge of the Neolithic cemetery. \\
4
\end{tabular}

Excavation Archive. A ${ }^{14} \mathrm{C}$ date of $7606 \pm 35 \mathrm{BP}$ or $8354-8454$ cal BP (OxA-16161) from charcoal from a spit at a depth of 30-36 inches $(0.76-0.91 \mathrm{~m})$ provides the best estimate for the upper limit of the date range of the Early Holocene flexed burials here, and a date of $9995 \pm 40$ BP or 11 270-11 $698 \mathrm{cal} \mathrm{BP} \mathrm{(OxA-15157)} \mathrm{from} \mathrm{a} \mathrm{spit} \mathrm{at} \mathrm{a} \mathrm{depth} \mathrm{of} \mathrm{24-36}$ inches $(0.61-0.91 \mathrm{~m})$ provides the best indication of the lower limit.

Although flexed burial appears to have been the normative or customary rite, more elaborate forms of 'secondary' burial were also practised whereby bodies were brought to the West Mouth to be buried there as part of a secondary process following an earlier primary burial or exposure elsewhere. Some bodies were cremated, others consisted of unburnt bones. An Early Holocene date is likely for the three 'seated' burials B54, B141 and B147 that form Burial Group 3 (Figure 5). Two bone apatite dates (GrN-7203: T. Harrisson 1975; N-1334: Brooks et al. 1977) can be rejected, but B147 later yielded a bone collagen date of $7020 \pm 135$ BP or 7594-8154 cal BP (N-1355). The complicated nature of the burial rites of these rare burials, involving the placing of the body on a fire lit on the base of a large and deep pit, suggests exclusive treatment for selected members of the community. The most unusual burials are B155 and B156, a pair of bound, flexed and decapitated individuals (Figure 6). B155 yielded a bone collagen date of 7850 1175 BP or 8837-9235 cal BP (N-1357; Brooks et al. 1977). The pairing and back-to-back positioning of these two individuals indicate that their graves were dug at the same time. Their location away from the front of the cave mouth also suggests that a deliberate spatial (and symbolic?) distance was maintained between this burial event and those of Burial Group 2. Even if the two burial areas were not exactly contemporaneous, it is reasonable to assume that those who performed the B155 and B156 decapitation burials belonged to a community for whom flexed burial was the normative rite and who knew the West Mouth as a place where 


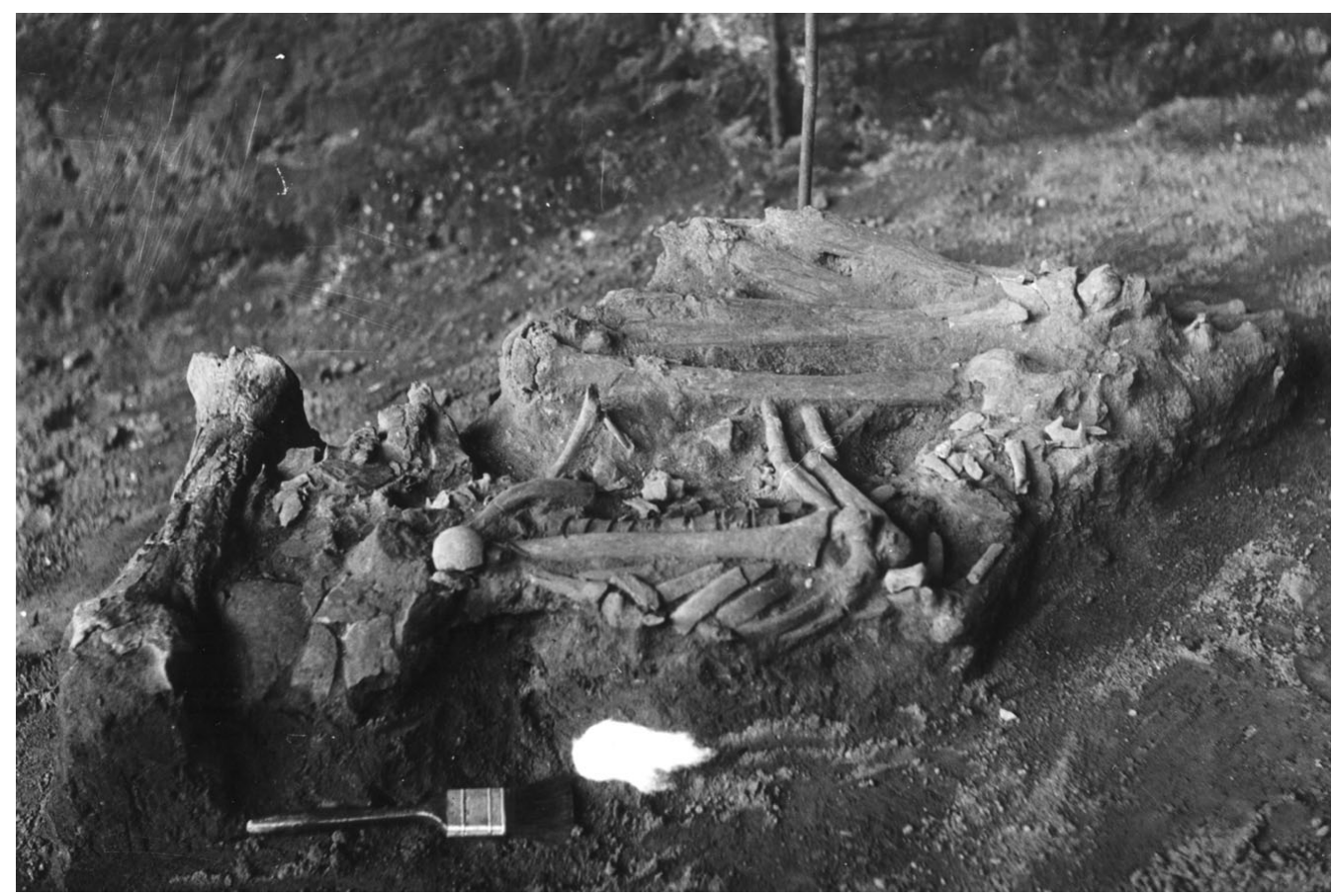

Figure 4. Early Holocene flexed burial B27 (photograph courtesy of Sarawak Museum).

people had lived and been buried with traditional rites. The spatial separation of the B155 and B156 burials may have symbolised a need to create social distance in death. Such an interpretation is further evoked by the separation of the head from the body, an action that divided a whole social being into parts. The focus on the skull in these burials foreshadows the selection, curation and reburial of skulls found in the extended primary and secondary burials of the Neolithic cemetery.

The creation of distinct clusters of interments in the West Mouth indicates the repeated use of the site for burial over periods of several centuries, with intervals in between, rather than sporadic occupation and site visitation over millennia. When people came to bury their dead they appear to have known where the burials should be placed in relation to earlier burials, remembering the locations and possibly the identities of particular burials. An indication of the possible spatial association of burials is the occurrence of similar items of material culture (rhinoceros bone and teeth) in the adjacent burials B27 (Figure 4) and B83. Whether by direct 'signposts' such as wooden grave markers (for which there is clear evidence in the Neolithic cemetery) or by word of mouth, ancestral identities were recognised and respected.

The Early Holocene burials from the West Mouth have parallels elsewhere in Southeast Asia. Isolated flexed burials likely to be of this date have been found at Gua Tengorak in western Kalimantan and at Kimanis in eastern Kalimantan (Arifin 2004). Isolated tightly flexed burials of Early Holocene age have been excavated within occupation or midden deposits in caves at Song Terus, Song Keplek and Gua Braholo in the Gunung Sewu 


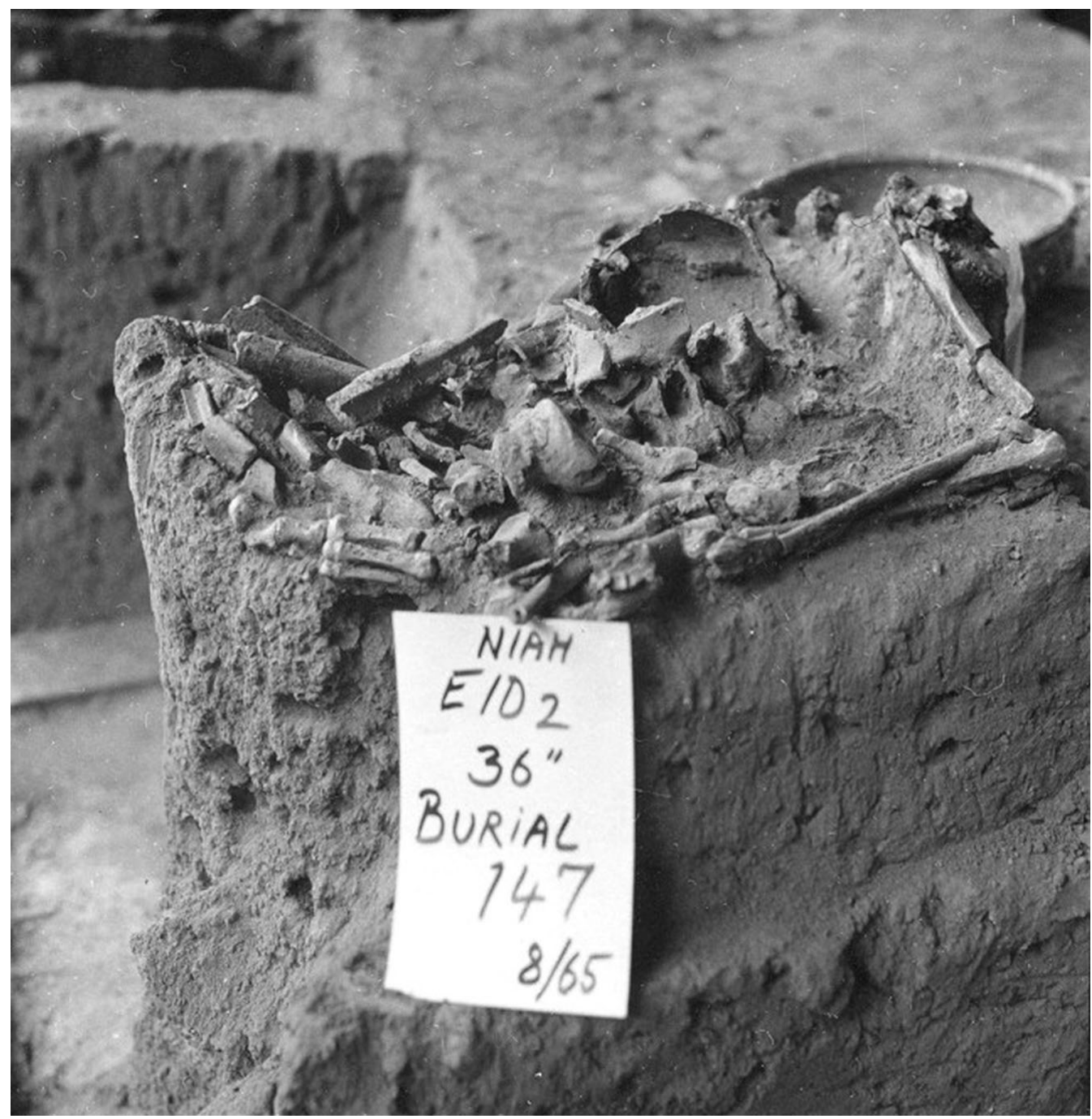

Figure 5. Early Holocene seated burial B147 (photograph courtesy of Sarawak Museum).

mountains of Java (Simanjuntak 2002). At Gua Braholo a secondary burial at the same level as and probably broadly contemporary with a flexed burial consisted of unburnt bones in a pit at the base of which was ash and charcoal, a sample of which produced a ${ }^{14} \mathrm{C}$ date of 8710 170 BP (Détroit 2006: 196), a situation reminiscent of the West Mouth seated burials placed into a fire pit. Seated burials were a common form of burial for Da But coastal communities in northern Vietnam (Viet \& Oanh 2002: 83-4). The probable antiquity of cremation burial at Niah gains support from cremation burials at Ille Cave on the island of Palawan in the Philippines, from which two samples of cremated bone produced dates of 9260-9006 cal BP (OxA-16020) and 9425-9280 cal BP (OxA-15982) (Lewis et al. 2008: 326). Combinations of primary flexed burials and secondary burials have been found in caves in the Malay Peninsula such as Gua Cha, Gua Teluk Kelawar and Gua Peraling 


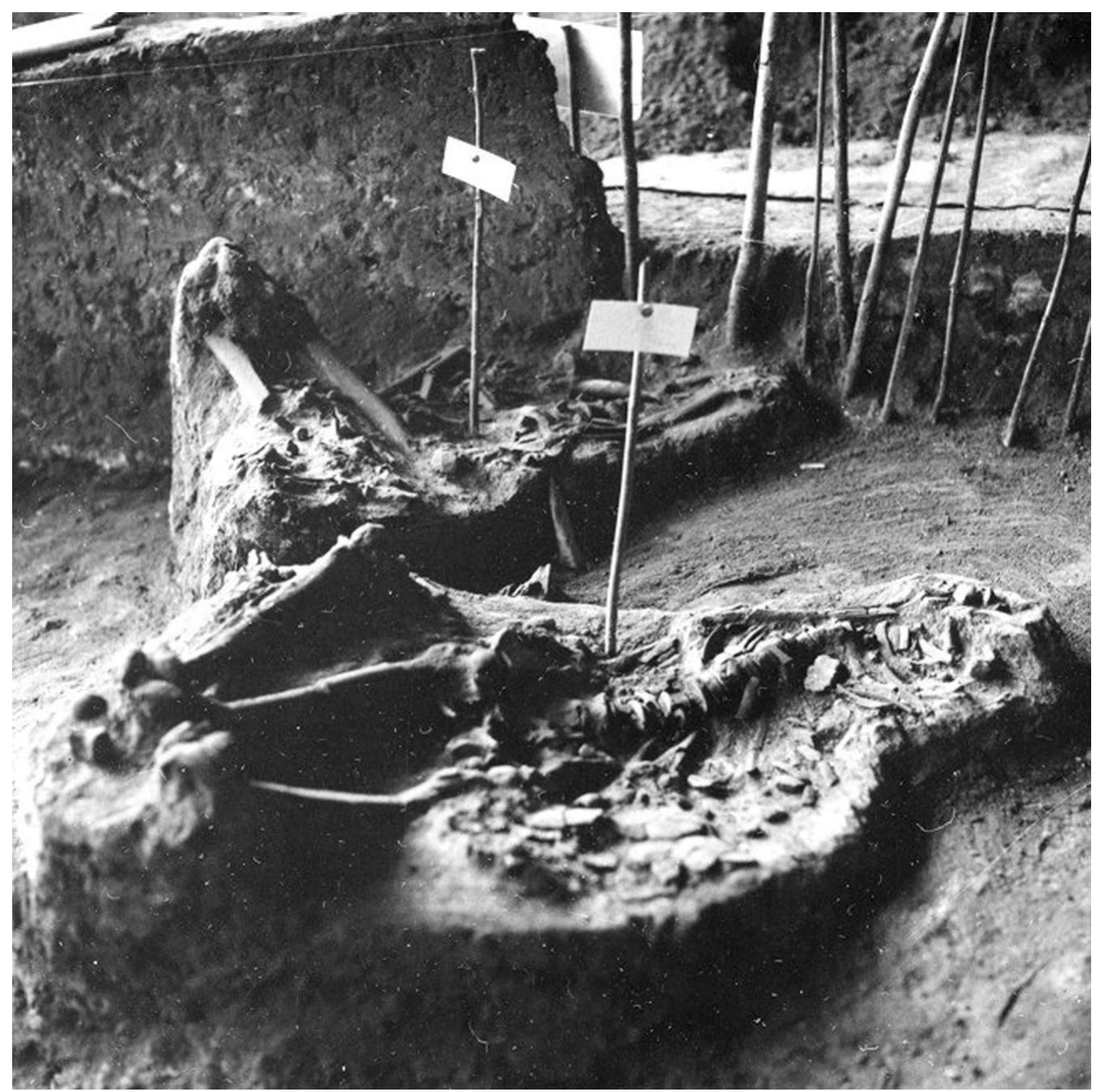

Figure 6. Early Holocene flexed decapitated burials B155 and B156 (photograph courtesy of Sarawak Museum).

(Zuraina Majid 2005). The indications are that Early Holocene people in Southeast Asia buried their dead either as primary flexed burials or as complicated secondary burials, at the same location, and, as far as we can tell within the limitations of archaeological chronologies, as a set of contemporary or overlapping funerary practices.

\section{'Neolithic' ritual practice and burial}

The charcoal ${ }^{14} \mathrm{C}$ dates from the West Mouth indicate a gap in the use of the cave between c. $8000 \mathrm{BP}$ and $4000 \mathrm{BP}$ - the Mid Holocene high sea stand might perhaps have made access to the caves difficult. The use of the West Mouth for burial by people with Neolithic material culture probably began as a series of sporadic and dispersed flexed burials dating 


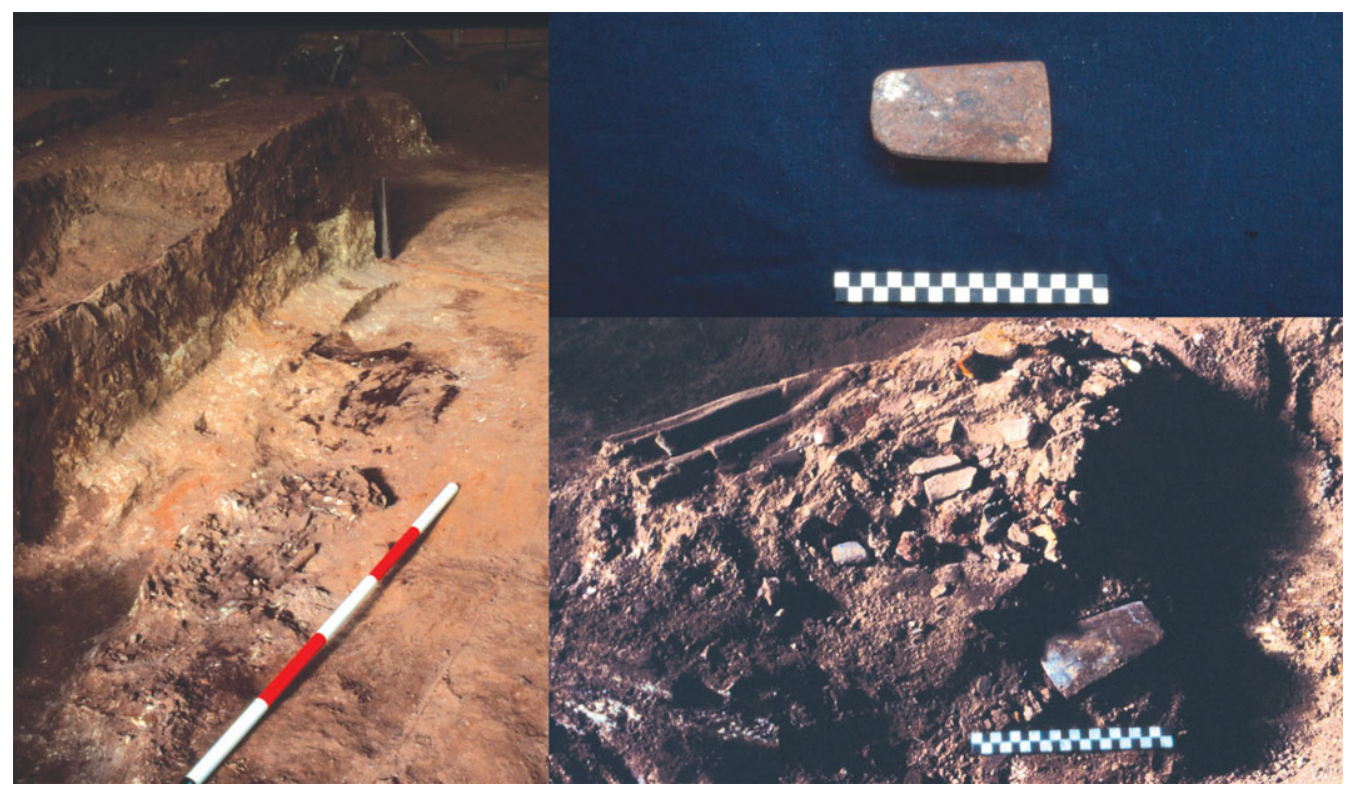

Figure 7. Flexed burial B205, looking north-east (left, scale $=1 \mathrm{~m}$ ), with a close-up view (top right) showing a Neolithic polished quadrangular adze that was buried with it (bottom right) (black \& white scales in cm) (photographs: G. Barker).

to sometime between $c .3500 \mathrm{BP}$ and $c .3300 \mathrm{BP}$. The earliest Neolithic burial dated is B205, first exposed in 1967 (described as 36 inches $(0.91 \mathrm{~m})$ below the ground surface) and re-excavated by the Niah Caves Project in 2003 (Barker et al. 2003: 69; Figure 7). This was flexed, like most of the Early Holocene burials, but was accompanied by a quadrangular polished stone axe, a classic item of Neolithic material culture. Compressed plant remains overlying B205, possibly associated with a later extended burial, were dated to $2986 \pm 29$ BP or 3072-3319 cal BP (OxA-13491).

There was a major change in mortuary practice after $c .3300$ BP: a formalised and structured cemetery was laid out, with rows of extended burials, frequently in wooden coffins or occasionally wrapped in a shroud. Grave goods included pots, stone axes and grinders, organic and clay beads, basketry and textiles (B. Harrisson 1967). Overall, the Neolithic cemetery dates between $c .3300$ BP and c. $2200 \mathrm{BP}$, during which six phases of burial can be discerned: primary flexed (3500-3300 BP); primary extended (3300-2900 BP); unburnt secondary burial (2900-2700 BP); secondary burial cremation (2800-2500 $\mathrm{BP}$ ); followed by a second phase of primary extended burial and, finally, a second phase of unburnt secondary burial (2500-2200 BP) (Lloyd-Smith 2009: 234). The regularity of the burial clusters within these phases suggests that they are likely to represent socially and/or temporally defined groups rather than randomly selected individuals: perhaps different family groups within a single community, or associated individuals from a number of different but related communities who used the West Mouth as a collective place of burial. There is no evidence for significant social differentiation.

The burial rites appear to have been focused on the veneration of immediate and recent ancestors. Comparisons with other Neolithic cemeteries in the Niah Caves complex such 
as Lobang Jeragan, Lobang Magala and Lobang Batu Parang (currently being studied by Franca Cole) indicate a shared history of developing funerary practices amongst a number of geographically-separate but socially-related communities living around the Gunung Subis. There are subtle differences in the assemblages of the different caves, and in the ways in which they were used in funerary practices, but the similarities are more striking than the differences, indicating that there were clear norms in funerary behaviour with wellrecognised boundaries, to which individuals and groups conformed. The complexities in the funerary data within and between the different burial sites suggest that different lineages with distinct ancestral traditions used different parts of the Niah Caves for burying their dead. The spatial relationships between male and female graves imply that these Neolithic societies may have been organised according to a matrilocal system of residence, in which a husband moved to his wife's household on marriage, though strontium isotope signatures show that non-local women were also marrying into the community on occasion (Valentine et al. 2008).

\section{'Neolithic' environment and subsistence}

The change from mangrove swamp to less saline vegetation somewhere between 6670 and $5850 \mathrm{cal} \mathrm{BP}$ (the age range of the ${ }^{14} \mathrm{C}$ dates in the two pollen cores taken near the Niah Caves) coincided with a marked change in sedimentation from freshwater peats to alluvial clays containing substantial quantities of Spirogyra spores: alga that requires sunlight to produce spores, indicating that the clays were accumulating in unshaded environments subject to seasonal flooding. This change suggests that large quantities of sediment were being liberated into the river system, and areas of open ground being created, presumably as a result of human clearance activities in the landscape (Hunt \& Rushworth 2005). As mentioned earlier, however, the evidence for more open landscapes around the caves, and active anthropogenic impacts, at the time of the Neolithic burials, may largely reflect the retreat of the coastal mangrove swamps that had invested the area in the Early Holocene, because the palynological record of Loagan Bunut a little further inland demonstrates a more or less continuous pattern of burning and clearance from the beginning of the Holocene until c. 6500 BP (Jones 2006; Hunt \& Premathilake in press).

The Early Holocene flexed and flexed decapitated burials have isotopic values suggestive of closed-canopy dietary regimes, whereas the Neolithic burials have open-canopy dietary signatures (Krigbaum 2001, 2005). Charred remains of morphologically-domestic rice have been found by Doherty et al. (2000) in sherds from 14 of the West Mouth Neolithic burials (in 14 sherds, out of almost 1500 examined from the cemetery); they are interpreted as accidental inclusions into the pottery fabric, rather than intentional temper. The lack of harvesting debris means that we cannot tell whether the occasional grains of domestic rice derive from crops grown locally or obtained by trade from elsewhere (and the clays of the fabrics of the vessels with rice remains are common across coastal north Borneo). The main plant foods in terms of calorific input into Neolithic diet, though, appear to have remained tubers, fruits and nuts. Hunting systems were fundamentally the same as in the Early Holocene. The first reliable zooarchaeological evidence for domestic pig in the region is a direct AMS date on a pig tooth from Nagsabaran on the island of Luzon in the northern 
Philippines, dated to $c .4500-4200$ BP (Piper et al. 2009), but currently domestic pigs are not known further south, including at Niah, until the Metal Age (the last two millennia). In terms of their dental morphology, all of the pigs in Neolithic contexts at Niah are wild (Cucchi et al. 2009). The zooarchaeological evidence correlates with molecular studies of the DNA of ancient and modern pigs in the region, which suggest that domestic pigs did not disperse across Island Southeast Asia until after the time of the presumed Austronesian migration $c$. 4000-3000 BP (Larson et al. 2007).

In summary, it appears that the 'Neolithic' people buried in the Niah Caves, like the 'Mesolithic' people before them, were primarily rainforest foragers, but were acquainted with domestic rice and from time to time may have practised its small-scale cultivation. Interestingly, the isotopic signatures of the people buried in the final phase of the Neolithic cemetery, in flexed burials, are 'closed-canopy', and there are indications in the contemporary sections of the Niah cores that the rainforest became more closed at this time. The inference is that, if the open-canopy diets of the Neolithic communities in the West Mouth cemetery were related at least in part to crop cultivation, including rice cultivation, people at Niah reverted to forest foraging c. $2000 \mathrm{BP}$.

\section{The Niah Caves population}

The physical characteristics of the people living in and around the Niah Caves through the Holocene fit uneasily with a model of indigenous Mesolithic foragers and incoming Neolithic farmers. Fifteen Mesolithic and 28 Neolithic burials from the West Mouth have been analysed in terms of four categories of morphological data: cranial metric and nonmetric, and dental metric and non-metric (Manser 2005). Though separated by several thousand years, the two populations were fundamentally of the same physical type, with no statistical differences in the upper and mid-face datasets. There was a significant reduction in the size of the teeth in the Neolithic skeletons compared with those of the Mesolithic, but this was interpreted in terms of dietary change, possibly associated with changes in food preparation, such as cooking.

\section{Discussion}

The Niah evidence indicates that foraging-farming transitions in this part of Island Southeast Asia were complex and ambiguous. Despite the gap of some 4000 years between the 'Mesolithic' use of the caves $c$. 11 500-8000 BP and the 'Neolithic' burials dating to $c$. 4000$2000 \mathrm{BP}$, the people on either side of the gap were of the same physical type, recognisably the same as people elsewhere in the region (Manser 2005). Both populations used the practice of flexed burial, and non-burnt secondary burials, as well as practising other forms of burial that were not shared between the two groups. The Mesolithic population relied entirely on the foods of the forest for its subsistence needs, and the Neolithic population largely so. The latter probably also engaged in small-scale rice cultivation, but may have reverted to foraging in the latter stages of the cemetery's history.

It is possible that people in northern Borneo were acquainted with rice well before its sporadic appearance in the Niah Neolithic ceramics: morphologically-domestic forms of rice 
phytoliths start to appear in the Loagan Bunut core from 8000 BP (Hunt \& Premathilake in press). If rice was indeed being exchanged between Island Southeast Asian communities long before its assumed introduction by Austronesian sailor-farmers, it would fit in with growing evidence for complex systems of maritime travel linking the communities of the region from at least the very beginning of the Holocene (Bulbeck 2008; Soares et al. 2008), when an area the size of Western Europe ('Sundaland') was flooded by rising sea levels leading to the formation of the present landscape. Plants, animals, people, material culture and information systems were all implicated in these pathways of movement, translocation, exchange and borrowing.

Both Mesolithic and Neolithic burial practices at Niah can be understood as sharing within region-wide traditions of the treatment of the dead, but there is also evidence for locally-distinct practices which, in the case of the Neolithic (when the West Mouth burials can be compared with other burial caves at Niah), can be detected at the very local scale of communities using burial caves a few hundred metres apart. Differences in mortuary practices and in isotope signatures of burials suggest that the Neolithic societies inhabiting the rainforests around the caves exchanged marriage partners with other communities beyond as well as within the Niah area. For example, one of three individuals identified as non-local from their strontium/lead ratios, in burial B160, had a heavy isotope signature comparable to three people buried in the Lobang Angin cave at Mulu some $80 \mathrm{~km}$ to the south-east of Niah (Valentine et al. 2008), and some of the Niah Neolithic pottery has specific similarities with the pottery used at Lobang Angin (Datan 1993). On the evidence of Niah, both Mesolithic and Neolithic people in Island Southeast Asia shared in complex networks of social interaction and material exchange at a variety of scales, from local to regional.

The evidence for the intensive use of nuts, fruits, sago palm and tubers by Mesolithic and Neolithic people using the Niah Caves, and the comparable evidence for Early Holocene plant use at Ille Cave (including of morphologically-domestic yam), fits into what Huw Barton and Tim Denham (Denham \& Barton 2006; Barton \& Denham 2011) have termed 'vegeculture': the tending, translocation and vegetative reproduction of tuberous plants. Such a system of forest management and resource enhancement would have its roots in the forest foraging systems practised by the first modern humans to use the Niah Caves c. 50000 years ago (Barker et al. 2007) as well as having echoes in how the present-day Penan foragers of Borneo protect and encourage key food plants such as sago (a system they refer to as molong: caring for the landscape). The emerging picture of a long history of tropical foraging systems incorporating arboriculture and vegeculture in Island Southeast Asia chimes with the indications from modern molecular studies of multiple domestication events across the region during the Early Holocene, for example of banana, sugarcane, yam and taro (Carreel et al. 2002; Grivet et al. 2004; Lebot et al. 2004; Malapa et al. 2005).

Although the people of Borneo may have been acquainted with rice much earlier than currently assumed, the scale of its cultivation by Neolithic people at Niah appears to have been very small. Also, it may not have been a staple food until recent centuries, on the evidence of rice remains in pottery (Doherty et al. 2000) and palynology (Yulianto et al. 2005). Today in Borneo the plants of both field and forest have complex meanings for people, as well as providing sustenance, but rice has sacred or quasi-sacred status — its 
growing is highly ritualised, and growing and eating it are associated with status and prestige (Janowski 2003). In the Kelabit Highlands both Kelabit rice farmers and Penan foragers recognise the special status of rice as the one plant that 'needs people to grow it', and how cultivating it, more than any other activity, separates people from the forest in a profound way - psychologically and spiritually as well as in terms of practical considerations of time and effort (Janowski \& Langub 2011). Thus, however small-scale its cultivation and dietary contribution until recent centuries, rice probably had an important social role from the time of its first introduction (Hayden 2001, 2003; Barton 2009).

\section{Conclusion}

The rich data from the Niah Caves for the character of 'Mesolithic' and 'Neolithic' lifeways partly support the emphasis of the 'Nusantao hypothesis' on the importance of maritime connections linking the indigenous communities of Island Southeast Asia through the Holocene, and partly the emphasis of the 'Austronesian hypothesis' on significant changes in material culture and land use in the period 4000-3000 BP. More importantly, though, they raise new questions that are poorly served by such meta-narratives: about how, over many millennia, neighbouring and far-distant communities engaged with each other; how and why particular forager communities reacted to new technologies, new food resources and perhaps new cosmologies associated with such foods. If many of the data fit very uneasily with an Austronesian Neolithic expansion, it remains true, nevertheless, as Peter Bellwood's regional syntheses have clearly demonstrated (e.g. Bellwood 1985, 1997), that there were significant changes in aspects of material culture across much of Island Southeast Asia between about 4000 and 3000 years ago - the time when Neolithic burial practices began in the Niah Cave. A regional assessment of Neolithic (Red-slipped) pottery assemblages has found that, whilst the assemblages of sites within different regions of Island Southeast Asia commonly share similarities, at the inter-regional level such links fall away, with no evidence of directionality (Swete Kelly 2009). Swete Kelly suggests that the loosely shared aspects of material culture - represented by Neolithic pottery and other artefacts - may be an outward indicator, not only of such expanding communication networks, but perhaps also of elite social groups 'buying into' components of Neolithic material culture as part of a process of signification and display. Could rice-eating and particular social behaviours associated with it have been an important component of such processes? The complexity of foraging-farming transitions at Niah suggests that new scenarios about the kind of historical processes that have resulted in present-day distributions of the Austronesian languages may need to be explored.

\section{Acknowledgements}

This paper draws on the work of the large team involved in the Niah Caves Project, whose work is fully described in Barker (in press). The primary funding for the fieldwork and laboratory work has been by the Arts and Humanities Research Council, with further funding from the UK Association of Southeast Asianists (ASEASUK) and the Natural Environment Research Council (ORADS Committee). Author contributions: Graeme Barker: project coordination; Lindsay Lloyd-Smith: funerary archaeology; Huw Barton: starch analysis; 


\section{Graeme Barker et al.}

Franca Cole: ceramics; Chris Hunt: palynology; Victor Paz: plant macrofossils; Philip Piper and Ryan Rabett: zooarchaeology; Katherine Szabó: molluscan analysis.

\section{References}

ARIFIN, K. 2004. Early human occupation of the East Kalimantan rainforest (the upper Birang River region, Berau). Unpublished $\mathrm{PhD}$ dissertation, The Australian National University

BARKER, G. (ed.) In press. Rainforest foraging and farming in Island Southeast Asia: the archaeology of the Niah Caves, Sarawak. Cambridge: McDonald Institute for Archaeological Research.

Barker, G., H. Barton, M. Bird, F. Cole, P. Daly, A. Dykes, L. Farr, D. Gilbertson, T. Higham, C. Hunt, S. Knight, E. Kurui, H. LeWIS, L. Lloyd-Smith, J. Manser, S. Mclaren, F. Menotti, P. Piper, B. Pyatt, R. Rabett, T. Reynolds, J. Shimmin, G. Thompson, \& M. TRICKETT. 2003. The Niah Cave Project: the fourth (2003) season of fieldwork. Sarawak Museum Journal 58(n.s.79): 45-120.

Barker, G., H. Barton, M. Bird, P. Daly, I. Datan, A. Dykes, L. Farr, D. Gilbertson, B. Harrisson, C. Hunt, T. Higham, L. Kealhofer, J. Krigbaum, H. Lewis, S. McClaren, V. Paz, A Pike, P. Piper, B. Pyatt, R. Rabett, T. Reynolds, J. Rose, G. Rushworth, M. Stephens, C. STRINGER, G. ThOMPSON \& C. TURney. 2007. The 'human revolution' in lowland tropical Southeast Asia: the antiquity of anatomically modern humans, and of behavioural modernity, at Niah Cave (Sarawak, Borneo). Journal of Human Evolution 52: 243-61.

Barker, G., C. Hunt, \& J. Carlos. 2011. Transitions to farming in Island Southeast Asia: archaeological, biomolecular and palaeoecological perspectives, in G. Barker \& M. Janowski (ed.) Why cultivate? Anthropological and archaeological approaches to foraging-farming transitions in Southeast Asia: 59-72. Cambridge: McDonald Institute for Archaeological Research.

BARTON, H. 2009. The social landscape of rice within vegeculture systems in Borneo. Current Anthropology 50(5): 673-5.

Barton, H. \& T. Denham. 2011. Prehistoric vegeculture and social life in Island Southeast Asia and Melanesia, in G. Barker \& M. Janowski (ed.) Why cultivate? Anthropological and archaeological approaches to foraging-farming transitions in Southeast Asia: 17-25. Cambridge: McDonald Institute for Archaeological Research.

Barton, H., P. Piper, R. Rabett \& I. Reeds. 2009. Composite hunting technologies from the Terminal Pleistocene and Early Holocene, Niah Cave, Borneo. Journal of Archaeological Science 36: 1708-1714.

BellwoOD, P. 1985. Prehistory of the Indo-Malaysian Archipelago. Sydney: Academic Press.

- 1988. A hypothesis for Austronesian origins. Asian Perspectives 26: 107-117.

- 1990. Foraging towards farming: a decisive tradition or a millennial blur? Review of Archaeology 11(2): 14-24.

- 1996a. The origins and spread of agriculture in the Indo-Pacific region: gradualism and diffusion or revolution and colonization? in D.R. Harris (ed.) The origins and spread of agriculture and pastoralism in Eurasia: 475-98. London: University College London Press.

- 1996b. Hierarchy, founder ideology and Austronesian expansion, in J. Fox \& C. Sather (ed.) Origin, ancestry and alliance: 18-40. Canberra: The Australian National University Press.

- 1997. Prehistory of the Indo-Malaysian Archipelago. Honolulu (HI): University of Hawai'i Press.

- 2004. First farmers: the origins of agricultural societies. Oxford: Blackwell.

Bellwood, P., R. Gillespie, G.B. Thompson, J.S. Vogel, I.W. Ardika \& I. Datan. 1992. New dates for prehistoric Asian rice. Asian Perspectives 31: 161-70.

BLUST, R. 1976. Austronesian culture history: some linguistic inferences and their relations to the archaeological record. World Archaeology 8: 19-43.

Brooks, S.T., R. Helgar \& R.H. BroOKs. 1977. Radiocarbon dating and palaeoseriology of a selected burial series from the Great Cave of Niah, Sarawak, Malaysia. Asian Perspectives 20: 21-31.

BulBECK, D. 2008. An integrated perspective on the Austronesian diaspora. Australian Archaeology 67: 31-51.

Carreel, F., D. Gonzalez de Leon, P. Lagoda, C. Lanaud, C. Jenny, J.P. Horry \& H. Tezenas du MONTCEL. 2002. Ascertaining maternal and paternal lineage within Musa chloroplast and mitochondrial DNA RFLP analyses. Genome 45: 679-92.

Cucchi, T., K. Dobney \& M. Fujita. 2009. New insights into pig taxonomy, domestication and human dispersal in Island Southeast Asia through molar shape analysis: the Sus remains from Niah and Lobang Kudih caves in Sarawak. International Journal of Osteoarchaeology 19: 508-530.

DATAN, I. 1993. Archaeological excavations at Gua Sireh (Serian) and Lubang Angin (Gunung Mulu National Park), Sarawak, Malaysia (The Sarawak Museum Journal Special Monograph 6). Kuching: Sarawak Museum. 
Denham, T. \& H. BARTON, 2006. The emergence of agriculture in New Guinea: a model of continuity from pre-existing foraging practices, in D. Kennett \& B. Winterhalder (ed.) Behavioral ecology and the transition to agriculture: 237-64. Berkeley (CA): University of California Press.

DÉTroit, F. 2006. Homo sapiens in Southeast Asian archipelagos: the Holocene fossil evidence with special reference to funerary practices in East Java, in T. Simanjuntak, I. Pojoh \& M. Hisyam (ed.) Austronesian diaspora and the ethnogeneses of people in Indonesian Archipelago: 186-204. Jakarta: Indonesian Institute of Science.

Diamond, J.M. 1988. Express train to Polynesia. Nature 336: 307-308.

Diamond, J. \& P. BellWoOd. 2003. Farmers and their languages: the first expansions. Science 300: 597-603.

Doherty, C., P. BeavitT \& E. Kurui. 2000. Recent observations of rice temper in pottery from Niah and other sites in Sarawak. Bulletin of the Indo-Pacific Prehistory Association 19: 147-52.

Grivet, L., C. Daniels, J.C. Glaszman \& A. D'HoNT. 2004. A review of recent molecular genetics evidence for sugarcane evolution and domestication. Ethnobotany Research and Applications 2: 9-17.

Harrisson, B. 1967. A classification of Stone Age burials from Niah Great Cave, Sarawak. Sarawak Museum Journal 15: 126-200.

HARrisson, T. 1957. The Great Cave of Niah: a preliminary report on Bornean prehistory. Man 57: 161-6.

- 1958. The Caves of Niah: a history of prehistory. Sarawak Museum Journal 8: 549-95.

- 1965. 50000 years of Stone Age culture in Borneo. Smithsonian Institution Annual Report 964: 521-30.

- 1970. The prehistory of Borneo. Asian Perspectives 13: $17-45$.

- 1975. Early dates for 'seated' burial and burial matting at Niah Caves, Sarawak (Borneo). Asian Perspectives 18: 161-5.

HaYDEN, B. 2001. The dynamics of wealth and poverty in the transegalitarian societies of Southeast Asia. Antiquity 75: 571-81.

-2003 . Were luxury foods the first domesticates? Ethnoarchaeological perspectives from Southeast Asia. World Archaeology 34: 458-69.

Hunt, C.O. \& R. Premathilake. In press. Early Holocene vegetation, human activity and climate from Loagan Bunut, Malaysian Borneo. Quaternary International.
Hunt, C.O. \& G. Rushworth. 2005. Cultivation and human impact at $6000 \mathrm{cal}$ yr BP in tropical lowland forest at Niah, Sarawak, Malaysian Borneo. Quaternary Research 64: 460-68.

JanOwski, M. 2003. The forest, source of life; The Kelabit of Sarawak. Kuching: Sarawak Museum \& London: British Museum.

JANOWSKI, M. \& J. LANGUB. 2011. Footprints and marks in the forest: the Penan and the Kelabit of Borneo, in G. Barker \& M. Janowski (ed.) Why cultivate? Anthropological and archaeological approaches to foraging-farming transitions in Southeast Asia: 117-27. Cambridge: McDonald Institute for Archaeological Research.

JONES, S.E. 2006. Palynological reconstruction of tropical lowland vegetation at Loagan Bunut, and the possible implications of forest disturbance. Unpublished MSc dissertation, Queen's University Belfast.

Krigbaum, J. 2001. Human paleodiet in tropical Southeast Asia: isotopic evidence from Niah Cave and Gua Cha. Unpublished PhD dissertation, New York University.

- 2005. Reconstructing human subsistence in the West Mouth (Niah Cave, Sarawak) burial series using stable isotopes of carbon. Asian Perspectives 44: 73-89.

Larson, G., T. Cucchi, M. Fujita, E. Matisoo-Smith, J. Robins, A. Anderson, B. Rolett, M. Spriggs, G. DOlman, T.-H. KIM, N.T.D. Thuy, E. Randi, M. Doherty, R.A. Due, R. Bolt, T. Djubiantono, B. Griffin, M. Intoh, E. Keane, P. Kirch, K.-T. Li, M. Morwood, L.M. Pedrina, P.J. Piper, R.J. Rabett, P. Shooter, G. VAN DEN Bergh, E. West, S. Wickler, J. YuAn, A. CoOper \& K. Dobney. 2007. Phylogeny and ancient DNA of Sus provide new insights into Neolithic expansion in Island Southeast Asia and Oceania. Proceedings of the National Academy of Sciences of the United States of America 104: 4834-9.

Lebot, V., M.S. Prana, N. Kreike, H. van Heck, J. Pardales, T. Okpul, T. Gendua, M. Thongjiem, H. Hue, N. VieT \& T.C. Yap. 2004.

Characterisation of taro (Colocasia esculenta (L.) Schott) genetic resources in Southeast Asia and Oceania. Genetic Resources and Crop Evolution 51: 381-92.

Lewis, H., V. Paz, M. Lara, H. Barton, P. Piper, J. Ochoa, T. Vitales, A.J. Carlos, T. Higham, L. Neri, V. Hernandez, J. Stevenson, E.C. Robles, A. Ragragio, R. Padilla, W. Solheim II \& W. RonQUillo. 2008. Terminal Pleistocene to Mid Holocene occupation and an early cremation at Ille Cave, Palawan, Philippines. Antiquity 82: 318-35. 
LLOYD-SMITH, L. 2009. Chronologies of the dead: later prehistoric burial practice at the Niah Caves, Sarawak. Unpublished PhD dissertation, University of Cambridge.

Malapa, R., G. Arnau, J.L. Noyer \& V. Lebot. 2005. Genetic diversity of the greater yam (Dioscorea alata L.) and relatedness to D. nummularia Lam. and D. transversa $\mathrm{Br}$. as revealed with AFLP markers. Genetic Resources and Crop Evolution 52: 919-29.

MAnser, J. 2005. Morphological analysis of the human burial series at Niah Cave: implications for late Pleistocene-Holocene Southeast Asian human evolution. Unpublished PhD dissertation, New York University.

PaWley, A. \& R.C. Green. 1973. Dating the dispersal of the Oceanic languages. Oceanic Linguistics 12: $1-67$.

Piper, P.J., H.-C. Hung, F.Z. Campos, P. Bellwood \& R. SANTIAGO. 2009. A 4000 year-old introduction of domestic pigs into the Philippine Archipelago: implications for understanding routes of human migration through Island Southeast Asia and Wallacea. Antiquity 83: 687-95.

SimanJUnTaK, T. 2002. Gunung Sewu in prehistoric times. Yogyakarta: Gadjah Mada University Press.

Snow, B.E., R. Shutler, D.E. Nelson, J.S. Vogel \& J.R. SOUTHON. 1986. Evidence for early rice cultivation in the Philippines. Philippine Quarterly of Culture and Society 14: 3-11.

Soares, P., J.A. Trejaut, L. Jun-Hun, C. Hill, M. Mormina, C.-L. LeE, Y.-M. Chen, G. Hudjashov, P. Forster, V. Macaulay, D. Bulbeck, S. OpPenheIMER, M. LiN \& M.B. RICHARDS. 2008. Climate change and postglacial human dispersals in Southeast Asia. Molecular Biology Evolution 25: 1209-1218.

Solheim, W. 1984. The Nusantao hypothesis: the origin and spread of Austronesian speakers. Asian Perspectives 25: 77-88.
SpriggS, M. 1989. The dating of the Island Southeast Asian Neolithic: an attempt at chronometric hygiene and linguistic correlation. Antiquity 63: 587-613.

Swete Kelly, M. 2009. Prehistoric social interaction and the evidence of pottery in the northern Philippines. Unpublished PhD dissertation, The Australian National University.

Szabó, K., M.C. Swete Kelly \& A. Penalosa. 2004. Preliminary results from excavations in the eastern mouth of Ille Cave, northern Palawan, in V. Paz (ed.) Southeast Asian archaeology. Wilhelm G. Solheim II festschrift: 209-224. Diliman: University of the Philippines Press.

Valentine, B., G. Kamenov \& J. Krigbaum. 2008. Reconstructing Neolithic groups in Sarawak, Malaysia, using lead and strontium analysis. Journal of Archaeological Science 35: 1463-73.

VIET, N. \& OANH, N. 2002. Archaeology of death in Vietnam - from Hoabinhian to Dongsonian, in A. Karlstrom \& A. Kallen (ed.) Fishbones and glittering emblems: 81-8. Stockholm: Museum for Far Eastern Antiquities.

Yulianto, E., A.T. Rahardjo, D. Noeradi, D.A. Siregar \& K. HiraKaWA. 2005. A Holocene pollen record of vegetation and coastal environmental changes in the coastal swamp forest at Batulicin, South Kalimantan, Indonesia. Journal of Asian Earth Science 25: 1-8.

Zuraina MajID. 2005. The Perak Man and other prehistoric skeletons of Malaysia. Penang: Universiti Sains Malaysia Pusat Penyelidikan Arkeologi Malaysia. 